\title{
What Role for International Organizations in the Promotion of Community Interests? : Reflections on the ideology of Functionalism
}

Klabbers, Johannes Antonius Maria

Oxford University Press

2018

Klabbers , J A M 2018 , What Role for International Organizations in the Promotion of Community Interests? Reflections on the ideology of Functionalism . in E Benvenisti \& G Nolte (eds) , Community Interests Across International Law . Oxford University Press, Oxford , pp. 86-100 . https://doi.org/10.1093/oso/9780198825210.003.0006

http://hdl.handle.net/10138/317199

https://doi.org/10.1093/oso/9780198825210.003.0006

unspecified

acceptedVersion

Downloaded from Helda, University of Helsinki institutional repository.

This is an electronic reprint of the original article.

This reprint may differ from the original in pagination and typographic detail.

Please cite the original version. 
What Role for International Organizations in the Promotion of Community Interests? Reflections on the Ideology of Functionalism

Jan Klabbers ${ }^{1}$

I. Introduction

Ever since Pierre Kazansky and Paul Reinsch published their classic works on international organizations in the early twentieth century ${ }^{2}$, international organizations have been regarded as not just promoting community interests, but as actually embodying the community interest. International organizations are conceptualized as taking care of things that states cannot or will not do on their own, and have come to be associated with the global common good. They are conceptualized as representing the common interest in a world of otherwise egoistic states, and the ultimate expectation has always been, in Nagendra Singh's wonderfully evocative phrase, to contribute to the 'salvation of mankind'. ${ }^{3}$ International organizations were created to perform collective tasks and make the world a better place, eventually leading, through 'networks of interdependence' ${ }^{4}$ and the 'logic of ramification', to a 'working peace system' ${ }^{5}$ Swords were to be turned, as the Bible has it, into plowshares ${ }^{6}$, and it was this sentiment that prevailed for a long, long time.

That picture of organizations as harbingers of world peace was never fully plausible. For one thing, it would be decidedly odd for nasty states to set up entities to work for the common good, and in this light it is no

\footnotetext{
${ }^{1}$ Academy Professor (Martti Ahtisaari Chair), University of Helsinki; Visiting Research Professor, Erasmus Law School, Rotterdam.

2 Pierre Kazansky, 'Les premiers éléments de l'organisation universelle', (1897) 29 Revue de Droit International et de Législation Comparée, 238-247; Pierre Kazansky, 'Théorie de l'administration internationale', (1902) 9 Revue Générale de Droit International Public, 353-367; Paul S. Reinsch, Public International Unions, Their Work and Organization: A Study in International Administrative Law (Boston: McGinn and Co., 1911). For commentary, see Jan Klabbers, 'The Emergence of Functionalism in International Institutional Law: Colonial Inspirations', (2014) 25 European Journal of International Law, 645-675.

${ }^{3}$ Nagendra Singh, Termination of Membership of International Organisation (London: Stevens and Sons, 1958), at vii.

${ }^{4}$ Harold K. Jacobson, Networks of Interdependence: International Organizations and the Global Political System, $2 \mathrm{~d}$ ed. (New York: Alfred Knopf, 1984).

5 David Mitrany, 'The Prospect of Integration: Federal or Functional?', (1965) 4 Journal of Common Market Studies, 119149.

${ }^{6}$ One of the classic texts on the role of international organizations carried this biblical motto in its title: see Inis L. Claude, jr., Swords into Plowshares: The Problems and Progress of International Organization (New York: Random House, 1956).
} 
coincidence that rationalist theories of international relations and international law have always had a hard time fitting international organizations into their models, and could eventually only start to do so by downplaying both the 'bad' to be expected from states and the 'good' to be expected from international organizations. On such a conception, organizations turned not into the opposite of states, but into their instruments: powerful states could use organizations to serve their individual purposes. ${ }^{7}$

Second, whereas Reinsch had written about some thirty entities which all had a reasonably clearly defined public task (public health, regulating means of communication, economic standardization), following the writings of Sayre the notion of international organization started to mushroom beyond control. ${ }^{8}$ Sayre, writing only a decade after Reinsch, saw fit to discuss all sorts of imperialist ventures as international organizations, providing them with a degree of legitimacy they might otherwise never have acquired. For him, entities such as the Chinese river commissions, or international police forces operative in the Balkans and North Africa, were as fine examples of international organizations as, say, the Universal Postal Union or the various health bureaux. And ever since, the notion of international organization has come to encompass essentially any form of interstate cooperation beyond the purely incidental, including entities devoted to military matters (North Atlantic Treaty Organization - NATO) and entities that are essentially interest groupings, such as the Organization of Petroleum Exporting Countries (OPEC), the Organization of Islamic Cooperation (OIC), or the European Union (EU). While such organizations may possibly contribute to the global public good, they will by definition prioritize the good of their member states - as their respective charters make clear. ${ }^{9}$

It also became clear that the more active international organizations became, the more they would engage in the sort of practices that would attract criticism. The International Tin Council (ITC) experienced a meltdown and became insolvent, leaving a number of creditors in the dark, and the activities of the United Nations (UN) and the EU in administering international territory suggested that when acting in governmental fashion, these entities could potentially be just as bad as the states they were supposed to displace. Horror stories arose regarding the way the United Nations High Commissioner for Refugees (UNHCR) was running refugee camps ${ }^{10}$, or about the decidedly authoritarian management of food crises in the Horn of Africa by the Food and Agriculture Organization (FAO) ${ }^{11}$, or about nepotism and corruption looming large in the UN Educational,

\footnotetext{
7 Paradigmatic is Robert O. Keohane, After Hegemony: Cooperation and Discord in the World Political Economy (Princeton NJ: Princeton University Press, 1984).

${ }^{8}$ Francis B. Sayre, Experiments in International Administration (New York: Harper and Brothers, 1919).

9 See also Jan Klabbers, 'Unity, Diversity, Accountability: The Ambivalent Concept of International Organization', (2013) 14 Melbourne Journal of International Law, 149-170.

${ }^{10}$ Guglielmo Verdirame, The UN and Human Rights: Who Guards the Guardians? (Cambridge University Press, 2011).

11 Graham Hancock, Lords of Poverty (London: Mandarin, 1989).
} 
Scientific and Cultural Organization (UNESCO). ${ }^{12}$ Whatever else such events and occurrences may have signified, they signified at the very least that the salvation of mankind would not automatically involve international organizations. International organizations, it transpired, could actually do wrong, and for the last three decades international organizations lawyers and academics have been struggling to develop ways of handling such situations, and how to integrate this insight into the prevailing legal theoretical framework. ${ }^{13}$

During this time, it has also become increasingly clear that there is a theoretical issue at the heart of the discipline of international institutional law, an issue inherent perhaps in the study of law generally. On the one hand, heuristically it makes perfect sense to utilize a broad, open concept of international organization. When studying international organizations, one might as well include inter-state interest groups such as the EU or OPEC; military alliances such as NATO; judicial organs such as the International Court of Justice (ICJ) and International Criminal Court (ICC), as well as all kinds of informal creatures, from G20 to Basel Committee and from the Paris Club to the Council of the Baltic Sea States. When it comes to studying patterns of inter-state cooperation, there is little point in excluding some merely on the basis of some random a priori marker. ${ }^{14}$

On the other hand, when it comes to treating international organizations not as object of study, but as subjects of law (and, importantly, beneficiaries of legal arrangements), then all of a sudden some distinctions would appear desirable. Surely, international courts cannot, like other organizations, be seen as exercising delegated powers - at least not without jeopardizing the independence of the judiciary. While it is one thing to grant tax immunities to organizations working for global health, should one really apply the same benefits to an organization whose mission is to make oil-rich states even richer? And while it is one thing to make benefits acceptable to entities that are willing to subject themselves to international law including fundamental ordering mechanisms such as sovereign equality, how desirable is it to offer legal protection to clubs that otherwise do not wish to be bound by international legal rules and deny their existence takes place on the plane of law altogether? ${ }^{15}$

\footnotetext{
12 Yves Beigbeder, Management Problems in United Nations Organizations: Reform or Decline? (London: Frances Pinter, 1987).

${ }^{13}$ Jan Klabbers, 'The EJIL Foreword: The Transformation of International Organizations Law', (2015) 26 European Journal of International Law, 9-82.

${ }^{14}$ See also Jan Klabbers, 'Formal Inter-governmental Organizations', in Jacob Katz Cogan, lan Hurd and lan Johnstone (eds.), Oxford Handbook of International Organizations (Oxford University Press, forthcoming).

${ }^{15}$ It remains a curious spectacle that the proudly extra-legal Organization for Security and Cooperation in Europe (OSCE) nonetheless was very keen to acquire legal privileges and immunities: this reeks of having one's cake and eating it too.
} 
Hence, some academic international organizations lawyers ${ }^{16}$ are torn between two logics: a heuristic logic, according to which a broad concept of international organization is useful, and a normative logic, according to which such a broad conception may be questionable. Traditionally, this has remained hidden from sight: following the idea that organizations are the harbinger of world peace, the swords-turned-plowshares contributing to the salvation of mankind, the heuristic and normative logics become one. On such an idea, there should be as many international organizations as possible, and all of them should enjoy immense benefits and derive protection from the body of legal rules applicable to them. This has become calcified into a theory of functionalism, and it is no exaggeration to claim (and I will substantiate this below) that functionalism has become ideology.

Still, if it is no longer entirely plausible to consider international organizations as embodying the community interest, the question remains whether and how international organizations can be expected to help promote the community interest. I will address in what ways organizations are thought to contribute to the community interest, followed by a brief discussion of functionalism as ideology. Before going there, however, it might be useful to explain why coercion is not the most obvious way in which international organizations can contribute to the community interest, despite a recent study suggesting as much.

\section{Coercive Organizations?}

The most obvious way, one would think, for international organizations to promote the community interest would be through the task of policing whether states and others live up to their obligations under international law, and indeed, to some extent this takes place - provided, of course, those obligations are themselves emanations of the community interest. Hence, theoretically, two relevant questions are raised. First, how can coercion or enforcement (I will speak of coercion, both because it is a more evocative term, and because coercion is the harder case: it assumes enforcement even against the wishes of the entity concerned) be philosophically justified, and second, is the existence of a community interest a conditio sine qua non?

\footnotetext{
${ }^{16}$ Not all, of course, perhaps not even a majority: many will happily suggest that the notion of organization should be broad, and that all of them should be treated generously by the law. The pessimist might add that there might not be any alternative at any rate: it is difficult to make normatively relevant substantive differentiations between organizations. See Klabbers, 'Unity, Diversity, Accountability'.
} 
In a recent study, the philosopher Carmen Pavel argues forcefully that international organizations can help enforce community obligations by coercing states, and by this she means, grosso modo, the organization's member states. ${ }^{17}$ By far the best part of the book is her justification of intervention by international institutions in the domestic affairs of states. These states, so she suggests, derive their sovereignty from their citizens, and should not act in such a way as to violate the basic rights of those citizens. As federalism makes clear, sovereignty can be divided. Pavel's study is a compelling plea to divide sovereignty between states and their international institutions, in such a manner that those institutions can be called on to intervene when necessary. In doing so, she provides, one might say, a philosophical justification for the responsibility to protect doctrine: citizens provide states with certain tasks, and delegate guardianship over those tasks to international organizations. ${ }^{18}$

While she has valuable things to say about the role of institutions and the relevance of how they are designed, nonetheless when it comes to the practical implementation she faces some stubborn obstacles. For one thing, it proves difficult to come up with examples of institutions that actually can exercise coercion: her main two candidates are both problematic. One the one hand, she (understandably) often refers to the ICC, but to consider the ICC an international organization on a par with, say, the Universal Postal Union (UPU) or the World Health Organization (WHO) seems to be stretching things. As noted, it is conceptually awkward to treat judicial institutions in terms of the type of principal-agent theory prevailing in the law of international organizations: this would be difficult to reconcile with the independence of the judiciary. ${ }^{19}$

Second, there are repeated references to the Security Council. Here, the pedant may point out that the Council is not best seen as an independent international organization. Legally speaking, it is one of the organs of the UN, and lacks legal personality. This may sound innocuous, but it has been authoritatively suggested that only organizations with international legal personality can incur responsibility under international law. ${ }^{20}$ Hence, on this point Pavel's reasoning leaves a gap, in that it presupposes that the Security Council can stand in for the UN and represents the UN.

\footnotetext{
${ }^{17}$ See Carmen E. Pavel, Divided Sovereignty: International Institutions and the Limits of State Authority (Oxford University Press, 2015)

${ }^{18}$ For a related construction of sovereignty as trusteeship, though focusing more on third parties, see Eyal Benvenisti, 'Sovereigns as Trustees of Humanity: On the Accountability of States to Foreign Stakeholders', (2013) 107 American Journal of International Law, 295-333.

${ }^{19}$ She is not alone in this: see also, e.g., Karen J. Alter, 'Delegation to International Courts: Self-binding versus Otherbinding Delegation', (2008) 71 Law and Contemporary Problems, 37-76.

${ }^{20}$ See Article 2(a) of the Articles on Responsibility of International Organizations.
} 
The third entity Pavel mentions is NATO, and here a different issue becomes visible, as NATO's coercive powers are primarily, perhaps exclusively, exercised over non-member states. Hence, it would take an additional argument or line of thinking to justify why NATO would have the authority to operate in, say, Afghanistan (which, to be sure, is not among its member states). Pavel's divided sovereignty argument does little work here, as it cannot be meaningfully suggested that the Afghan population has mandated NATO to intervene in Afghan affairs. Pavel's justification covers intervention in the organization's member states (thus, NATO would be allowed to intervene in Norway, say, or Canada), but cannot on its own justify intervention in non-member states. Here then Pavel needs to resort to standard liberal argumentation and the jus cogens nature of fundamental rights: since all states have agreed on outlawing certain practices, everyone may intervene to enforce the norms protecting citizens against those practices. But if so, then the 'divided sovereignty' justification becomes superfluous: on this basis, Russia would be entitled to intervene in Myanmar, and the US could happily intervene in North Korea. Coercive international institutions would not be necessary.

But even if the idea of coercion proves difficult to justify especially over those who have not been able to express their consent, it is nonetheless clear that some coercive acts by international organizations do take place. First and foremost among these are sanctions imposed by the Security Council. This used to be philosophically fairly straightforward: until the early 1990s, the UN imposed sanctions which would typically meet with two conditions: they would be imposed on member states, and would be imposed for violations of community norms, typically norms considered by many to represent jus cogens. This applied to the sanctions against Rhodesia and South Africa over Apartheid and related forms of discrimination; it even applied to Iraq over its use of aggression against Kuwait.

A change of sorts started in the early 1990s, when sanctions were first imposed on not a member state, but a liberation movement, i.e. Angola's Unita. ${ }^{21}$ Here, one cannot claim that the member state concerned was involved, in that Unita denied the authority of the state of Angola to represent the people, and it would be rather far-fetched to claim Unita would have consented to the authority of the Security Council. The same problem transpires with the smart or targeted sanctions that have been imposed ever since: their justification must reside somewhere else than in the consent of the state of which those individuals are nationals.

This would not be too much of a problem if at least they could be justified in terms of jus cogens, but this is not unequivocally the case. Many of the coercive measure imposed have been imposed over allegations of terrorist involvement in one way or another, which can range from supplying terrorism suspects with regular goods and

${ }^{21}$ Sydney D. Bailey, The UN Security Council and Human Rights (New York: St. Martin's Press, 1994$), 43$. 
services to financing their operations. Two broad comments are in order. First, while the global 'war on terror' undeniably received a boost after 9/11, it is not certain that terrorism is prohibited as a matter of jus cogens or, more accurately, that the sanctioned activities are themselves part of any jus cogens prohibition of terrorism. Most often, the sanctions target individuals whose involvement is usually mostly indirect - the targeted individuals are not themselves terrorists, most of the time. Now sociologically there can be all sorts of causation at work here, but the law is usually rather strict with causation (for better or for worse): imposing sanctions on someone who sent money to a relative who then uses it to buy supplies for suspected terrorists may make descriptive sense, but the law usually stops a few steps short of making such connections.

The second comment is this: even if terrorism and acts surrounding it were prohibited as a matter of $j u s$ cogens, so too might be the rules that guarantee a fair trial and access to justice. So coercive measure might be justified, but their application ought to meet with fairly basic human rights standards lest the coercion itself becomes problematic. And the proposition that targeted sanctions imposed by the Security Council meet with such standards is a proposition not even the Council's greatest defenders would seriously claim. ${ }^{22}$

Hence, while international organizations undoubtedly on occasion engage in coercive measures, the proper justifications for this remain problematic. Moreover, and more fundamentally still, it remains to be seen whether coercive measures are actually taken in the community interest. For, the entire claim rests on the possibility that one can meaningfully speak about community interests, as interests that cannot be reduced to those of a group of powerful states to be maintained against the wishes of those who disagree or who have different interests. This therewith raises a different kind of argument: how do organizations possibly contribute to the creation of the community interest?

III. Promoting the Community Interest

It is a truism - but a necessary one to repeat - that there is no such thing as a community interest in sheer isolation from particular interests. Put differently, community interests are a matter of epistemology, not

${ }^{22}$ Indeed, a voluminous literature has arisen suggesting that this is not the case. Some of the more eye-catching contributions include Jeremy Farrall, United Nations Sanctions and the Rule of Law (Cambridge University Press, 2007); Antonios Tzanakopoulos, Disobeying the Security Council: Counter-Measures Against Wrongful Sanctions (Oxford University Press, 2011); and Devika Hovell, The Power of Process: The Value of Due Process in Security Council Sanctions Decision-Making (Oxford University Press, 2016) 
ontology, and are constructed by the relevant actors. ${ }^{23}$ It is here that international organizations play perhaps their most important role: in helping to shape the perception that something is, or is not, a community interest. If this is correct, it also follows that the 'community interest' need not necessarily be something widely embraced by the liberal community of international lawyers. Most international lawyers will associate the 'community interest' with such things as human rights protection or environmental protection, and with the type of activities often captured under headings such as jus cogens rules or erga omnes obligations typically, international lawyers adhere to more or less cosmopolitan and liberal theories of global justice. Yet, such conceptualizations are far from automatically given: the 'community interest', lacking ontological roots, is an infinitely malleable concept.

Perhaps the most obvious way in which organizations can contribute to the common interest, highlighted by generations of functionalist international lawyers and more recently by liberal institutionalist scholars as well, is by their very existence. Typically, organizations exist as platforms for discussion as well as instrumental entities that are supposed to 'just do it'. Their creation reduces transaction costs and engenders stability, certainty and predictability. To the extent that they work on the basis of the 'one state, one vote' principle ${ }^{24}$, moreover, they can be seen as a step up from nineteenth century power politics, where smaller states just had to obey the commands of the Great Powers. ${ }^{25}$ And in being based on 'one state, one vote' they even suggest an affinitive link with democracy, however subliminal perhaps: how else to call the situation where the mighty US has as much to say as Lilliputian Liechtenstein? How else to characterize the situation where the giant and the dwarf are considered to be equals?

So, organizations tick a number of cosmopolitan normative boxes merely by existing. Their presence stimulates quintessentially liberal values such as predictability and stability. In bringing states together, they conform to the old adage, colouring so much of international law, that 'some agreement between states is always better than no agreement at all'. ${ }^{26}$ In being organized, for the better part and at least on paper, around ideas of sovereign equality, they make fleeting reference to democratic thought - a kind of democracy innuendo.

\footnotetext{
${ }^{23}$ Similarly Friedrich Kratochwil, The Status of Law in World Society: Meditations on the Role and Rule of Law (Cambridge University Press, 2014), esp. 135-167.

${ }^{24}$ Many organizations employ this, at least with respect to their plenary organs - it may entail though that the politically relevant organ is not the plenary. A major exception is formed by the financial institutions; see Jan Klabbers, 'On Functions and Finance: Sovereign Debt Workouts and Equality in International Organizations Law', (2016) 41 Yale Journal of International Law, forthcoming.

${ }^{25}$ Bengt Broms, The Doctrine of Equality of States as Applied in International Organizations (Vammala: Vammalan Kirjapaino, 1959).

${ }^{26}$ The same sentiment underlies the curious popularity of notions such as soft law. For one formulation, see Christine M. Chinkin, 'The Challenge of Soft Law: Development and Change in International Law', (1989) 38 International and
} 
Obviously, there are also more tangible ways of formulating the community interest, for instance by adopting resolutions or other instruments. Here, organizations benefit from the circumstance that they are the agorae of the global community: the UN General Assembly in particular is the 'town meeting' of the world in a relevant, non-pejorative sense. ${ }^{27}$ It is the one platform where well-nigh all states come together on a regular basis; where all can have their say, and it is additionally a platform not hindered by a sense of having to accomplish things. Since the Assembly lacks legislative powers, it is not expected, normally, to be 'effective', or to engage in 'crisis management'. Hence, much of the Assembly's energy can go into shaping notions of the community interest. ${ }^{28}$

Throughout the years, the Assembly has done much to shape and reshape the community interest. Its most famous attempt to do so was the proclamation of the Universal Declaration of Human Rights, sparking the human rights revolution and paving the way for the two UN Covenants and a host of other human rights related treaties concluded under auspices of the Assembly, ranging from the not terribly successful convention on the rights of migrant workers to the more recent convention on the rights of persons with disabilities. Later efforts have included such initiatives as the proclamation of a new international economic order, and various ways of trying to end poverty, first by proclaiming a right to development, later by focusing more on the plight of individuals by setting the so-called Millennium Development Goals.

Likewise, and despite its more managerial mandate, the Security Council too has managed to elevate issues to matters of international concern and thus, perhaps, the community interest. One example was when it first adopted a resolution on $\mathrm{HIV} / \mathrm{Aids}^{29}$; more recent examples include references to the Ebola virus in securitydominated instruments. ${ }^{30}$ On the other hand, it is not implausible to claim that these were already recognized as 'of international concern', just not of concern to the Security Council - the politics of 'framing' looms large here. $^{31}$

Comparative Law Quarterly, 850-866, at $861:$ ' ... a soft law form is preferable to either no outcome at all to negotiations, or to a treaty with diluted and vague provisions.'

27 Jan Klabbers, 'Two Concepts of International Organization', (2005) 2 International Organizations Law Review, 277-293.

${ }^{28}$ It can also go into other directions, as exemplified by the nonsensical and obnoxious equation of Zionism and racism in General Assembly Resolution 3379 (XXX) of 10 November 1975.

${ }^{29}$ See Security Council Resolution 1308 (2000) of 17 July 2000.

${ }^{30}$ See, for instance, S/RES/2203 of 18 February 2015 on Guinée-Bissau, para. 17. See more generally Gian Luca Burci and Jakob Quirin, 'Ebola, WHO, and the United Nations: Convergence of Global Public Health and International Peace and Security', at http://www.asil.org/insights/volume/18/issue/25/ebola-who-and-united-nations-convergence-global-publichealth-and (last visited 26 August 2015).

${ }^{31}$ On the relevance of framing, see, e.g., Nancy Fraser, Scales of Justice: Reimagining Political Space in a Globalized World (New York: Columbia University Press, 2009). 
Much the same applies to other international organizations. As a general matter, their role as public platforms allows them to focus attention on whatever matter they see fit. Thus, not only does the protection of employees generally owe much to the work of the International Labour Organization (ILO), the ILO was instrumental more particularly in placing the connection between labour and migration on the political agenda. Maritime security and safety is among the general work of the International Maritime Organization (IMO), but the IMO also raises specific matters to the international plane. The United Nations Conference on Trade and Development (UNCTAD) is formally an entity of broad economic compass, but has recently helped to transform sovereign debt relief from a matter between debtor and creditors to a matter of community interest; and it is at least arguable that the concerted effort of the WHO and its then director-general Gro Harlem Brundtland have done much to construe tobacco consumption as a matter of international concern. That said, sometimes organizations also miss the proverbial boat: for all its effectiveness in placing labour and migration on the agenda, it remains curious that the ILO has done very little on the topic in recent years. ${ }^{32}$ Either way though, it is clear that organizations can contribute to the community interest in that they help to formulate how the community interest should be understood - they operate as norm entrepreneurs, both in placing items on the global political agenda, making them be seen as matters of community interest, and in providing the platforms for legal regulation. ${ }^{33}$

Organizations sometimes also have other means at their disposal, means that may actually come to re-define the understanding of 'community interest' in more subtle ways. Perhaps the prime example here resides in the 'structural adjustment policies' as advocated by the International Monetary Fund and implemented in bilateral loan agreements. Whatever else their effects, these have resulted in elevating a certain particularist way of looking at the economy and turned it into a universally adhered to set of economic values. More generally, the practices of the international financial institutions have contributed to a conception of the community interest as dependent on markets rather than states: they have helped to create and sustain the idea that economic values should prevail, and that the only - or at least most - relevant measure is the one of loss and profit. ${ }^{34}$ The so-called Washington Consensus was supposed to reduce inequalities within and between states and be

\footnotetext{
${ }^{32}$ See Jan Klabbers, 'Marginalized International Organizations: Three Hypotheses Concerning the ILO', in Ulla Liukkunen and Chen Yifeng (eds.), China and ILO Fundamental Principles and Rights at Work (Alphen aan den Rijn: Wolters Kluwer, 2014), 181-196.

${ }^{33}$ Note that this corresponds to at least two of the dominant views on power as conceptualized by political scientists: the power to take decisions, and the power to set the agenda. The third is the power to get others to think what you want them to think, and will be discussed below. See Steven Lukes, Power: A Radical View (London: MacMillan, 1974).

${ }^{34}$ Some have sketched a fairly direct connection between the Economics Department of the University of Chicago (traditionally dominated by free marketeers) and the policies of the financial institutions. See Naomi Klein, The Shock Doctrine (London: Penguin, 2007).
} 
accompanied by basic human rights protection and respect for democracy, and eventually result in global peace, indeed eternal peace: often this was grounded in a (sometimes perhaps somewhat superficial) reading of the writings of Immanuel Kant. ${ }^{35}$

Either way, much of what is generally seen as the community interest is the work of international organizations. ${ }^{36}$ The notion of 'good governance' rose to prominence within the UN Development Program; slogans such as that a 'rising tide lifts all boats' may illustrate the liberalization of trade sponsored by the World Trade Organization (WTO) ${ }^{37}$; the Organization for Economic Cooperation and Development (OECD) has developed all sorts of initiatives on financial management and against corruption (and administers the Financial Action Task Force), and has recently even managed to give pride of place to global taxation. In doing so, it aims to promote the common interest but, importantly, a version of the common interest that is particularistic in its origins. And in doing so, it assists in legitimizing those particularist projects.

In fact, it has been suggested, and rather cogently so, that organizations may sometimes create their own versions of the community interest, perhaps in order to prolong their own existence and raise their own relevance. A prime example is how the World Bank discovered 'poverty' as an issue of global interest (the word is absent from its Articles of Agreement), and later seized on the notion of 'sustainable development' and the necessity of 'greening' its operations and policies. These are examples of how the World Bank helps to construct (or reconstruct) the world around it in ways that cannot be captured properly by any principal/agent based theory, including the theory of functionalism. ${ }^{38}$ Other examples are not hard to come by either, and may range from the UN evolving from a collective security mechanism to a global welfare machine, having elevated such things as drugs control to a matter of community interest; or NATO changing from a self-defense alliance into a global police force after the demise of communism.

Perhaps it is worth noting though that some of the most important issues stem not from formal international organizations, but from less highly institutionalized forms of cooperation, in particular the G20. If the OECD has managed to raise the profile of global taxation, it was the $\mathrm{G} 20$ who first adopted it under the somewhat euphemistic label of combatting Base Erosion and Profit Shifting (BEPS). Other policy initiatives too may sometimes spring from the G20 and be further explored in other rather informal fora: sovereign debt relief,

\footnotetext{
${ }^{35}$ See, e.g., Fernando R. Tesón, A Philosophy of International Law (Boulder CO: Westview, 1998).

${ }^{36}$ This is hardly a coincidence, in that much of international law is the result of the work of these creatures. See Matthias Ruffert and Christian Walter, Institutionalisiertes Völkerrecht (Munich: Beck, 2009)

${ }^{37}$ Erin Hannah, James Scott and Silke Trommer (eds.), Expert Knowledge in Global Trade (Abingdon: Routledge, 2016).

${ }^{38}$ Balakrishnan Rajagopal, 'From Resistance to Renewal: The Third World, Social Movements, and the Expansion of International Institutions', (2000) 41 Harvard International Law Journal, 529-578.
} 
e.g., is often associated not just with UNCTAD but also with the so-called Paris Club, a club predominantly composed of creditor states in order to help discuss debt relief of debtor nations but without a clear constitution, a clear mandate, or even clear rules on membership or decision-making beyond the injunction that decisions require consensus among the creditor states. ${ }^{39}$ This, incidentally, also exposes the risk involved in fragmenting the world into bite-size topics: while both UNCTAD and the Paris Club address sovereign debt relief, they do so in different ways, involving different actors, starting from different premises and resulting in different solutions. ${ }^{40}$ Or, put differently, different organizations may come to promote different versions of the community interest, even on what is broadly the same topic.

It is, quite possibly, also telling that some of the generally accepted challenges of the day have hardly resulted in common action and are generally outside the mandates of any particular international organization. Poverty, migration and environmental justice are not within the more or less exclusive remit of any single organization, and neither is financial regulation. Some of these fall with the mandate of several organizations at the same time: combating extreme poverty, e.g., can be seen to be inherent to the work of the UN, driven by a coalition of poorer nations and thus coming with a welfarist tinge, as well as the financial institutions dominated by western states and generally driven by a market-orientation. It is not just the case that this results in coordination issues: it also comes with deep philosophical cleavages as to how best to engage in combating extreme poverty.

Migration, by contrast, is largely the province of the International Organization for Migration (IOM), but this organization's constitution formulates its mandate in terms almost diametrically opposed to a community interest: its brief is premised on guaranteeing the 'orderly flow of migration movements', according to the preamble of the IOM's constitution, and the list of purposes of the organization also speaks predominantly in terms of what the IOM can do for its member states, as opposed to either migrants or the international community. This suggests, once again, that mere international cooperation, or mere institutionalization, need not necessarily serve a community interest: the community interest, it seems, must be distinguished from the collective interests of states.

Financial governance may, to some extent, be in the hands of the financial institutions, but these essentially scrutinize the macro-economic policies of governments, and typically of governments in developing nations:

${ }^{39}$ According to its website, the Paris Club is self-described as an 'informal group of official creditors' with 20 permanent members but allowing for ad hoc participation, where decisions are based on six principles. There seems to be no constituent document. See http://www.clubdeparis.org/en/ (last visited 26 August 2015).

${ }^{40} \mathrm{~A}$ useful discussion of some of the issues is Yvonne Wong, Sovereign Finance and the Poverty of Nations: Odious Debt in International Law (Cheltenham: Edward Elgar, 2012). 
they do not exercise much control or influence over the actions of central banks - or private banks - in developed economies. This is to some extent mitigated (if that is the right word to use) by the Basel Committee and its Guidelines on Banking Supervision, but these stem, once again, from an entity of debated legal standing and are themselves of debated legal status. ${ }^{41}$

To sum up: international organizations can play a role in formulating the community interest, but are, first, not the only ones who can do so, and second, will often do so from their own vantage points: the community interest according to the WTO will look different, very different, from the community interest according to the United Nations Environment Programme (UNEP). Indeed, there is increasing recognition of competition between organizations, not just over their proper turf ${ }^{42}$, but ideological competition. The above-mentioned reframing of HIV/Aids and Ebola as security issues already point in this direction: signifying some kind of competition between the UN and the WHO. But this can go further. Not very well-known is that a number of territories usually considered tax havens have set up the International Trade and Investment Organization (ITIO) so as to provide a counterweight to the OECD's attempts to regulate global taxation. ${ }^{43}$ More visibly, China sponsored the creation, in 2015, of the Asian Infrastructure Investment Bank (AlIB) as a direct alternative to the existing western-dominated financial institutions. The point of these institutions is to offer ideological competitors - it is to offer different conceptions of the community interest. And while Darwinian optimists may predict that this eventually entails that the fittest conception of the community interest will prevail, others may wonder whether a conception that is fit enough to survive will be of much use to the community interest - or whether it will simply be a particularist project with stronger backing than its competitors.

IV. Functionalism as Ideology

\footnotetext{
${ }^{41}$ The Basel Committee is part of the Bank for International Settlements which, as public organizations go, has a checkered history (it used to have private shareholders), but is generally considered an international organization. Still, the status of the BIS as an international organization says nothing about the legal force of the guidelines adopted by the Basel Committee, and many agree that these are formally indeed at best, as their name suggests, guidelines, though exercising great authority.

${ }^{42}$ As is inherent in the co-existence of different bureaucratic entities. For some gruesome examples, see Hancock, Lords of Poverty.

${ }^{43}$ For brief discussion, see Peter Carroll and Ainsley Kellow, The OECD: A Study of Organizational Adaptation (Cheltenham: Edward Elgar, 2011), 142.
} 
Friend and foe agree that international organizations law is dominated by a single body of thought, usually referred to as 'functionalism'. ${ }^{44}$ Functionalism suggests, as outlined above, that organizations are created by member states to perform certain functions, and that since these functions are generally considered to be in the community interest, it follows that the law's task is to facilitate the functioning of these entities. ${ }^{45}$ Hence, the law of international organizations places few (if any) limits on the reach of competences of international organizations; it allows organizations to admit, suspend, or expel member states with a view to its functioning; and it protects the functioning of organizations by all sorts of privileges and immunities. Moreover, it appears structurally unable to regulate control over international organizations by actors other than their own member states: since functionalism essentially organizes relations between the organization and its members, it has little to offer non-members, be they states, individuals, or civil society groupings. ${ }^{46}$

Functionalist thought has a strong hold on the imagination: wherever a transboundary problem or issue is identified, there will be calls to set up an international organization to address the problem, either through discussion or by taking decisive action, of the sort that states cannot (or cannot be expected to) realize on their own, and with the community interest in mind. As one authority recently put it, discussing climate change: '... it is essential to devise stronger and more efficiently organized international institutions, with functionaries who are appointed fairly by agreement on national governments, and empowered to impose sanctions. ${ }^{\prime 47}$

If functionalism can be considered theory, it is somewhat uncertain what kind of theory it is supposed to be. From one angle, since no existing international organization has ever met with the ideal type set up by functionalism, there is room for the argument that it has fairly little descriptive or explanatory force, and it is perhaps no coincidence that commentators tend to be reluctant to refer to functionalism as 'theory'. ${ }^{48}$ This

\footnotetext{
${ }^{44}$ They may quibble about the precise extent of domination, but not about the domination as such. See, e.g., Guy Fiti Sinclair, 'The Original Sin (and Salvation) of Functionalism', (2015) 26 European Journal of International Law, 965-973. ${ }^{45}$ This is, obviously, not the only type of investigation possible, and some shift attention away from the investigation of international institutional law to the investigation of the social, political or legal relevance of international organizations. Fine examples include Craig N. Murphy, International Organization and Industrial Change (Cambridge: Polity, 1994), and Guy Fiti Sinclair, 'State Formation, Liberal Reform and the Growth of International Organizations', (2015) 26 European Journal of International Law, 445-469.

${ }^{46}$ This is precisely why resort is had to a non-functionalist vocabulary in aiming to control organizations. The leading monograph is Eyal Benvenisti, The Law of Global Governance (The Hague: Hague Academy of International Law, 2014). I have addressed functionalism's problems with control elsewhere: see Jan Klabbers, 'Theorising International Organisations', in Florian Hoffmann and Anne Orford (eds.), Oxford Handbook of International Legal Theory (Oxford University Press, forthcoming), and Jan Klabbers, 'The Transformation of International Organizations Law'.

${ }^{47}$ The authority in question is Pope Francis, Encyclical on Climate Change and Inequality: On Care for Our Common Home (New York: Melville House, 2015) at 107.

${ }^{48}$ See Sinclair, 'Original Sin'. See also André Nollkaemper, 'Saving the Scarecrow', (2015) 26 European Journal of International Law, 957-964.
} 
reluctance is strengthened by functionalism's lack of precision: even if functionalism can predict that organizations may enjoy privileges and immunities, it cannot predict the precise extent thereof. Even if functionalism can justify admission or expulsion of member states, often political considerations overrule functional concerns. ${ }^{49}$ And even if it can predict that organizations may exercise implied powers, it is vulnerable to mood swings on the part of those who have to evaluate whether powers have been properly found and exercised. ${ }^{50}$ Moreover, functionalism has problems in actually identifying its own focal point: with many international organizations, it is not all that easy to specify what its main function or functions are, and much comes to depend on the level of analysis. Those who hold that the function of the EU is to achieve market integration in Europe are not wrong, but neither are those who suggest its function is to prevent war between Germany and France, nor even those who suggest its function is to achieve 'ever closer Union' - yet, these three different putative functions are capable of justifying radically different courses of action. Hence, in the end, the explanatory force of functionalism, while present in rough measure, is both limited and not very precise.

As a result, it is tempting to view functionalism not so much as engaged with empirical reality, but rather with setting a normative standard, as normative theory or ideal theory, not unlike, say, Rawls' theory of justice. ${ }^{51}$ The point of functionalism is not that it can be verified or falsified; the point is, rather, that it has guided many generations of international organizations lawyers in telling them how to think about international organizations and to solve practical legal problems under reference to the function of the organization. In short, functionalism is a normative theory or, differently put, an ideology. ${ }^{52}$ While the term 'ideology' has fallen into disuse and is usually associated with Marxian social theory and considered pejorative ${ }^{53}$, one does not have to be a Marxist to recognize that ideas and rhetoric can help to legitimate power. ${ }^{54}$ While this is done quite

\footnotetext{
${ }^{49}$ Alison Duxbury, The Participation of States in International Organisations: The Role of Human Rights and Democracy (Cambridge University Press, 2011).

50 Jan Klabbers, 'The Changing Image of International Organizations', in Jean-Marc Coicaud and Veijo Heiskanen (eds.), The Legitimacy of International Organizations (Tokyo: United Nations University Press, 2001), 221-255.

${ }^{51}$ John Rawls, A Theory of Justice (Oxford University Press, 1971).

${ }^{52}$ For the rather sweeping claim that international law as such is ideology, see Shirley V. Scott, "International Law as Ideology: Theorizing the Relationship between International Law and International Politics, (1994) 5 European Journal of International Law, 313-325.

${ }^{53}$ As Goldie puts it: 'To expose a belief as ideological has generally been part of a strategy of exposing such a belief as false.' See Mark Goldie, 'Ideology', in Terence Ball, James Farr and Russell L. Hanson (eds.), Political Innovation and Conceptual Change (Cambridge University Press, 1989), 266-291, at 267.

${ }^{54}$ For the various concepts of ideology in circulation, see the brief discussion in Susan Marks, The Riddle of All Constitutions: International Law, Democracy, and the Critique of Ideology (Oxford University Press, 2000), esp. at 9-10. My notion of ideology comes closest to the one Marks ascribes to Mannheim and his notion of Weltanschauung, with perhaps a sprinkling of Foucauldian thought for good measure, covering 'a framework of beliefs, values and concepts' defining 'the outlook of ... a social group' - in this case, international institutions and international institutional lawyers. The Foucauldian
} 
directly by international organizations in their field of action (in the sense in which the World Bank's ideology can be said to be neo-liberalism ${ }^{55}$ ), functionalism 'doubles up' the ideological nature of international organizations. Organizations espouse their own ideology, and the theory governing their operations further endorses the ideology associated with international organizations. If ideology is about presenting particular projects as universal ${ }^{56}$, then functionalism helps to do precisely this: it helps to present particular projects as universal, as being in the community interest, regardless of the particular project at issue. ${ }^{57}$ States may cooperate, e.g., to restrict migration - while this would not immediately be associated with any form of cosmopolitanism, when organized under auspices of an international organization (such as the IOM) the activity rapidly comes to be seen as somehow embodying a community interest. If states such as China or Russia individually fight against terror eyebrows may be raised and human rights concerns expressed; if they do so through the Shanghai Cooperation Organization, however, things look far more respectable -it is precisely by being cast in the format of international organization that the activities become salonfähig. ${ }^{58}$

\section{Concluding Remarks}

The present chapter has suggested that there are several ways in which international organizations contribute to formulating, maintaining and enhancing the community interest, but also that little of this is straightforward. Organizations can contribute to the community interest merely be existing and serving as a platform for the

sprinkling suggests that ideology needs to operate in tandem with actual mechanisms and techniques to be effective: see Michel Foucault, Society Must be Defended: Lectures at the Collège de France, 1975-76 (London, Penguin, 2003, Macey transl.), 33-34.

${ }^{55}$ James H. Mittelman, Whither Globalization? The Vortex of Knowledge and Ideology (London: Routledge, 2004), esp. 4755.

${ }^{56}$ Marx and Engels held as much, but with the twist that the particular projects were projects of the ruling class, and the identity of the ruling class was clear. See the brief discussion in Susan Marks, 'Introduction', in Susan Marks (ed.), International Law on the Left: Re-examining Marxist Legacies (Cambridge University Press, 2008), 1-29, at 7. One does not need to adhere to conceptions about ruling classes to appreciate the point though: see, e.g. Hans J. Morgenthau, Politics Among Nations, 2d ed. (New York: Alfred Knopf, 1955), at 80, pointing out that all politics contains elements of ideology, with the pursuit of power dressed up in other terms: legal, ethical, or otherwise.

${ }^{57}$ And it is hardly a coincidence that much praise is heaped on organizations in quasi-religious terms, such as Singh's claim that they contribute to the 'salvation of mankind', and Claude's analogy of swords and plowshares. It has been noted that ideology critiques become pervasive when religious doubt has set in: see Goldie, 'Ideology'.

${ }^{58}$ Tapping into the idea of international organizations (and therewith the functionalist ideology) can have a powerful legitimating effect, starkly illustrated by Russian soldiers painting their helmets blue when intervening in Moldova in 1992, prior to UN approval. The episode is recorded by lan Hurd, After Anarchy: Legitimacy and Power in the United Nations Security Council (Princeton NJ: Princeton University Press, 2007), 126. 
formulation of that interest. They can do so through coercion of member states or even others, although this is rare and not easy to justify. They can do so, more regularly, by developing ideas and consensus concerning the community interest and adopting documents to this effect or aspiring to this effect, and they do so, hidden from view but of great practical significance, by relying on the ideology of functionalism. Since the notion of community interest does not exist in isolation from particular projects, it always and by definition assumes someone pouring meaning into it.

That is not necessarily a bad thing. Pejorative as especially the term ideology may sound, it derives its pejorative association not from any particular content, but from its very modus operandi: ideology tends to cover up political projects and present them in a different, more flattering light. Hence, even the claim that functionalism is an ideology is merely claiming that it works covertly: it does not suggest on its own that it would normatively be undesirable, and should not be taken as such. The term ideology is best seen as a methodological device for laying bare aspects of reality that otherwise remain hidden from view, without implying a further normative evaluation of those aspects. The point, then, is not to disavow international organizations or functionalism tout court, but rather to recognize international organizations for what they are: always someone's political project, dressed up in terms of the community interest and operated by the ideology of functionalist thought. 